\title{
Europe agrees to seek new climate targets
}

London. Environment ministers of the 15 member states of the European Union (EU) have agreed to press for a new protocol on reducing carbon dioxide emissions beyond the year 2000 at the summit meeting on climate change in Berlin at the end of the month.

The decision was taken last Friday, in the run-up to the first meeting of signatories to the United Nations Framework Convention on Climate Change (FCCC) since the Earth Summit in Rio de Janeiro in 1992 at which the convention was signed. But there is still doubt whether EU states as a whole will fulfil their commitment to reducing greenhouse gases to their 1990 level.

The EU's decision is widely seen as indicating that it will try to take a lead in the Berlin negotiations, and will press for a mandate laying out the framework for the next series of commitments. These will probably to be agreed at the third conference of parties in 1997.

But judging by discussions at the Intergovernmental Negotiating Committee in New York last month (see Nature 373, 462; 1995), EU states are likely to face a wide range of alternative proposals put forward by other signatories to the convention.

The European environment ministers have yet to set any clear targets or time-scales for reductions after 2000 . But they did list possible measures, such as controlling emissions from large combustion plants - the only major emitter not to be regulated in the United Kingdom, for example - the use of economic instruments, the promotion of Tighter emission controls suggested new and renewable sources of energy and controls on transport.

Environmental groups say they are relieved that the proposals first agreed in December have not been watered down. But Matthew Spencer, atmosphere campaigner for Greenpeace UK, says that the main issue is "whether they will stick to their guns and actually push for the mandate, or cave in under pressure from countries such as the United States and Canada".

\section{Aid agency under fire in Brussels}

London. Edith Cresson, the European research commissioner, is refusing to increase support for an intergovernmental organization set up to channel European aid to scientists in the former Soviet Union (FSU) until the heavily-criticized agency improves its efficiency.

The 'International Association for the Promotion of Cooperation with Scientists from the Independent States of the FSU' known as INTAS - was set up in 1993 on the initiative of the then twelve member states of the European Union and five other European governments.

Backed, ironically, by Cresson's mentor as French prime minister, President François Mitterrand, the founding states promised to provide ECU50 million (US\$66 million) over two years to support joint projects involving scientists from the former Soviet Union (FSU) states working with colleagues in at least one European country.

By last summer, more than 500 projects had been approved in principle for funding. But many scientists have become increasingly frustrated at lengthy bureaucratic delays, in both Brussels and Moscow, which have resulted in some projects approved in 1993 still not being funded.

"It has been a total shambles," says Norman Dombey, of the department of physics at the University of Sussex. He was informed early in 1994 that a proposal for ECU23,000 involving physicists in Russia and Georgia had been approved, but says that none of the Georgian scientists has yet received any money.

INTAS officials admit that it has taken longer than initially anticipated to make the necessary arrangements to transfer funds to Russia and other FSU states. They point out, for example, that the contracts need to be signed by all the participating scientists.

Nevertheless, they claim that there has been a "incredible" improvement over the past few months in the number of new projects that have been finalized.

So far, however, the Commission appears to be unimpressed. Keen to maintain the momentum behind the scientific aid programme, various EU member states had been pressing for an increase in the ECU5 million that the Commission is planning to provide to INTAS this year to support further joint research projects.

At a meeting of the EU Council of Research Ministers in Brussels last Friday, Cresson said she thought that INTAS was a good idea. But she drew the ministers' attention to what she described as the "dysfunctioning" of the organization which, she said, had so far signed "a very limited number of contracts" with FSU scientists.

Rejecting suggestions from some states for increasing support for INTAS, an independent agency under Belgian law, to at least ECU12 million, Cresson said that the Commission was not prepared to increase its funding unless the organization "puts its management in order". David Dickson
Total carbon dioxide emissions in the EU are expected to increase by between five and eight per cent over 1990 levels by the year 2000, even though some individual couna tries are expected to meet their target of zero increase. These countries, which in总 clude the United Kingdom, are pressing for others to meet their target and commit themselves to new targets beyond 2000 .

The day before the environment ministers met in Brussels, the British government launched a report from the Department of Trade and Industry containing projections on UK energy use and the energy-related emissions of carbon dioxide between 1995 and 2020. Timothy Eggar, the energy minister, welcomed the report as the first to go beyond the year 2000 , but admitted that "the further one looks to the future the less easy it is to predict."

But John Gummer, the Secretary of State for the Environment, said Britain would not only press for commitments beyond 2000 at Berlin, but would be seeking to limit the emissions of all greenhouse gases. "Negotiations must start in Berlin towards agreeing new commitments which, using a comprehensive or 'basket' approach, would aim at beginning to reduce total greenhouse gas emissions in developed countries below 1990 levels."

The UK delegation will argue that the more time governments are given to think about new targets, the better equipped they will be to anticipate the measures that need to be taken and thus reduce the risk of drastic cuts in the future.

Fiona Gammie

\section{EC 'likely to reopen patent negotiations'}

Paris. The European Commission (EC) is under pressure from member states of the European Union (EU) to resurrect its attempts to develop a directive on patenting biotechnological inventions. This follows the rejection of a draft directive earlier this month by the European Parliament, concluding seven years of negotiations (see Nature 374, 103; 1995).

A Commission spokesman says that no formal decision has been made to propose a new version of the rejected directive. But one commission official says that, on the basis of discussions during an informal meeting of EU internal market ministers last weekend in the French resort of Biarritz, this outcome is "very likely". 